\title{
Immortalization of Embryonic Rat Mesencephalic Cells
}

\author{
H. Takashima, M. Marone*, H.M. Geller* and W.J. Freed \\ NIMH Neuroscience Center at St. Elizabeths, Washington, D.C., and \\ "Department of Pharmacology, Robert Wood Johnson Medical School, N.J., USA
}

Several kinds of immortalized cell lines from rodent brain have been reported. These show neuronal, glial, or bipotential properties. For the study of neural transplantation in relation to Parkinson's disease, development of immortalized dopaminergic cell lines may have the potential to provide an unlimited source of cells. Immortalized cell lines established by the introduction of temperature-sensitive oncogenes are expected to grow indefinitely at the permissive temperature. At the non-permissive temperature, such cells are expected to stop growing and may also show some differentiated properties.

In the present study, a retroviral vector with a temperature sensitive form of the SV40 large T antigen was employed to develop immortalized cell lines from the rat embryonic (E12-E14) ventral mesencephalon. Several cell lines have been developed and some of these have been characterized by immunohistochemical analysis under several conditions.

The ventral mesencephalon was dissected from E12-E14 Sprague-Dawley rat embryos. The cells were infected overnight with the supernatant of a $\Psi-2$ cell line, which stably produces a defective recombinant retroviral vector carrying neomycin resistance and the temperature-sensitive SV40 large $T$ gene (tsA58) inserted in the tZIP-Neo-SV(X)1 construct, at $33^{\circ} \mathrm{C}$ in the presence of $4 \mu \mathrm{g} / \mathrm{ml}$ of Polybrene. After infection, cells were kept in defined medium (DMEM/F12 supplemented with $25 \mu \mathrm{g} / \mathrm{ml}$ insulin, $100 \mu \mathrm{g} / \mathrm{ml}$ transferrin, $60 \mu \mathrm{M}$ putrescine, $20 \mathrm{nM}$ progesterone, $30 \mathrm{nM}$ T3, 30 $\mathrm{nM}$ selenium, $15 \mathrm{mM}$ HEPES, $4 \mathrm{mM}$ glutamine, $3.1 \mathrm{~g} / 1$ glucose) containing $20 \%$ conditioned medium from rat embryonic (E14) brain tissue culture at $33^{\circ} \mathrm{C}$ for three weeks. The medium was then replaced with DMEM/F12 (1:1) sup- plemented with $10 \%$ FCS (DMEM/F12/FCS) and $200 \mu \mathrm{g} / \mathrm{ml} \mathrm{G} 418$ in order to select cells that had integrated the retroviral DNA construct and were, therefore, resistant to this drug. G418 was left in the cultures for 10 days and then removed. Growing colonies were separated using cloning rings or limiting dilution, and then expanded.

The cells were seeded on uncoated chamber slides and stained for SV40 T antigen, neurofilament, N-CAMA, MAP2, GAP43, L1/NgCAM, tyrosine hydroxylase, Vimentin, A2B5, GFAP, S100, myelin basic protein, and fibronectin. For staining at $39.5^{\circ} \mathrm{C}$, the cells were grown to confluence and kept in DMEM/F12/ FCS for 5 days, then dissociated and seeded on uncoated chamber slides.

At the permissive temperature $\left(33^{\circ} \mathrm{C}\right)$ the clones appeared polygonal with only occasional short processes and were positive for SV40 T antigen. Doubling time was approximately 2-3 days in DMEM/F12/FCS. Clones stopped growing at the non-permissive temperature $\left(39.5^{\circ} \mathrm{C}\right)$, extended processes, and were negative for SV40 $\mathrm{T}$ antigen.

A cell line derived from E14 grew only in a monolayer and stopped growing when confluent, even at the permissive temperature. When these cells extended long processes, the processes were positive for neurofilament at both $33^{\circ} \mathrm{C}$ and $39.5^{\circ} \mathrm{C}$. This clone was also positive for $\mathrm{L} 1 / \mathrm{Ng}-\mathrm{CAM}$ at both temperatures. The other neuronal and glial markers were negative at both temperatures. A cell line derived from E13 grew in a multilayer. Neurofilament was negative at $33^{\circ} \mathrm{C}$. At $39.5^{\circ} \mathrm{C}$, when these cells extended long processes, the distal parts of the processes were positive for neurofilament. The other neuronal and glial markers were negative at both temperatures. A cell line derived from 
E12 grew in a multilayer. Neurofilaments and the other neuronal and glial markers were negative at both temperatures except when further stimulated.

When differentiation was further stimulated with a mixture of dibutyryl cAMP, 3-isobutyl-1methylxanthine (IBMX), and bFGF in DMEM/ $\mathrm{F} 12 / 10^{\circ} \mathrm{FCS}$ at $39.5^{\circ} \mathrm{C}$, each of these cell lines extended processes which were longer than without these substances. In the cell line from E14, the processes were positive for neurofilament and L1/Ng-CAM. In the cell lines from $\mathrm{E} 12$ and E13, the processes were positive for neurofilament only in their distal parts. Other neural and glial markers were negative.
In summary, temperature-sensitive immortalized cell lines derived from rat embryonic (E12-E14) ventral mesencephalic cells showed some neuronal properties. In the E14 cell line, neurofilament was expressed at both $33^{\circ} \mathrm{C}$ and $39.5^{\circ} \mathrm{C}$, although the non-permissive temperature increased the length of processes and concomitantly increased neurofilament expression. For the E13 cell line, only the distal parts of processes were neurofilament-positive at the nonpermissive temperature. In the cell line from E12, no neurofilament expression was observed at either $33^{\circ} \mathrm{C}$ or $39.5^{\circ} \mathrm{C}$, except when differentiation was further stimulated by dibutyryl cAMP, IBMX, and bFGF. 

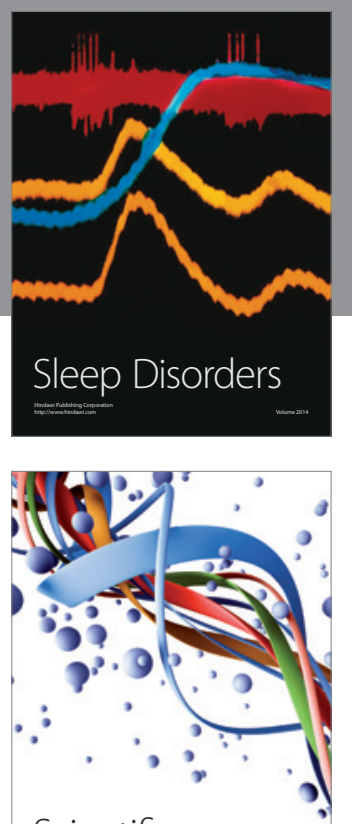

Scientifica
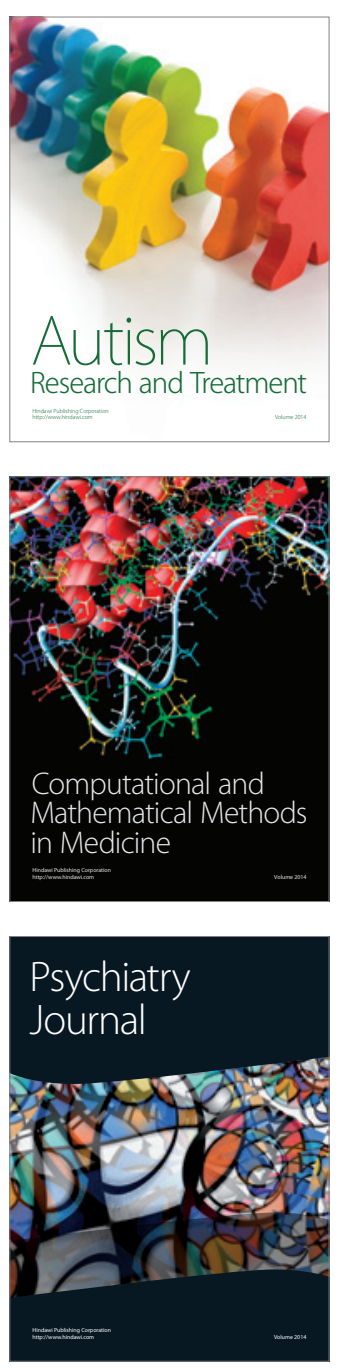
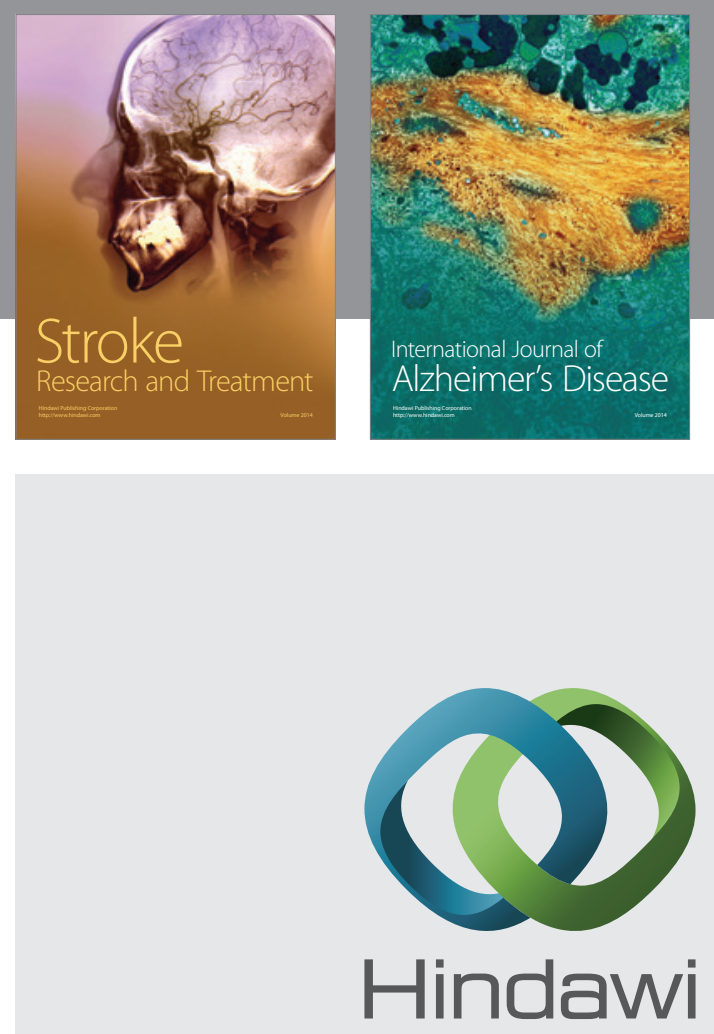

Submit your manuscripts at

http://www.hindawi.com
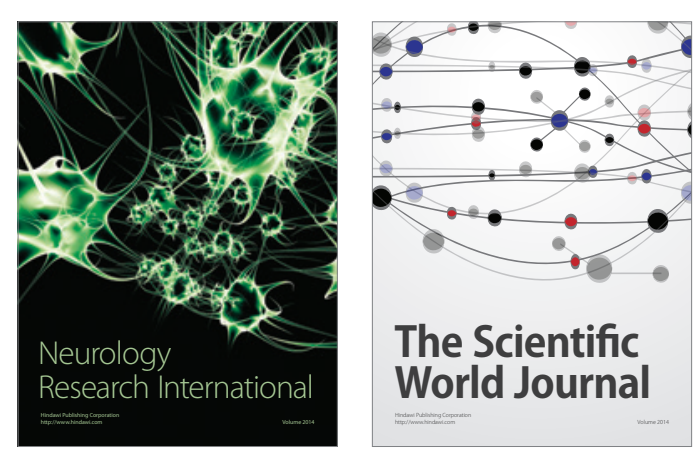

The Scientific World Journal

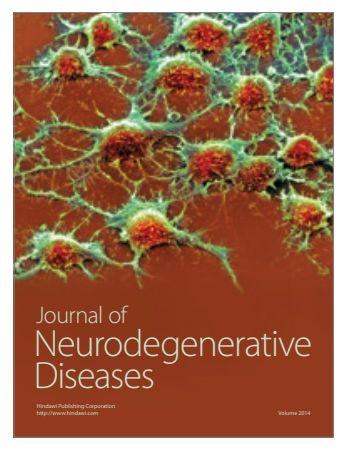

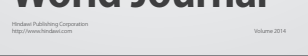

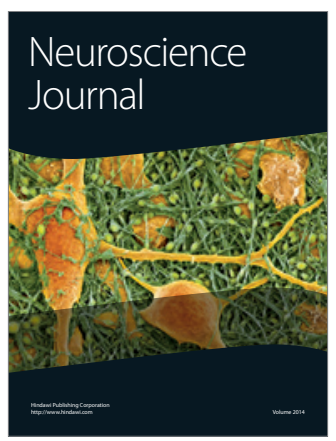

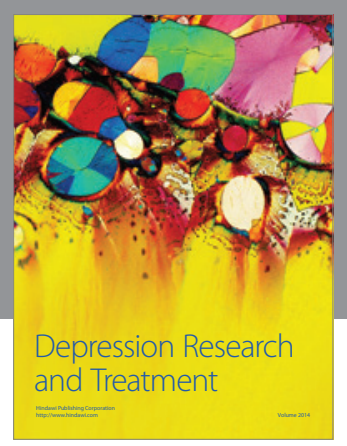
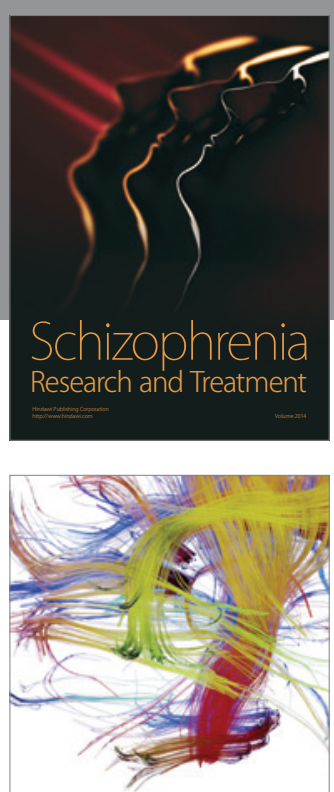

Brain Science

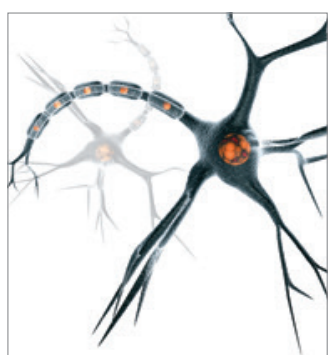

Neural Plasticity
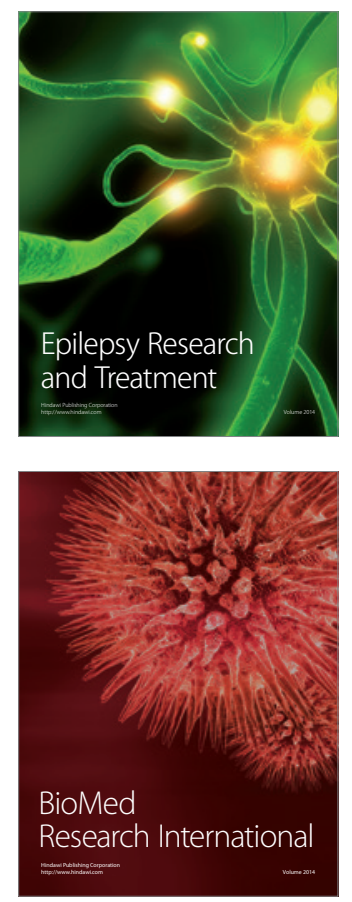

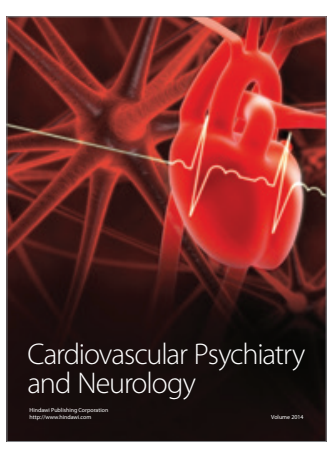

Parkinson's

Disease
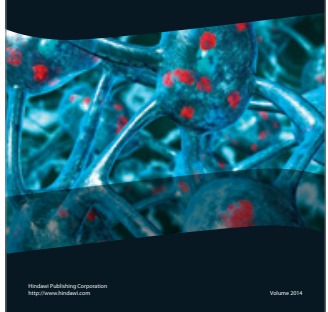